\title{
Free radical scavenging activity and antioxidative potential of various solvent extracts of Mussaenda macrophylla Wall: An in vitro and ex vivo study
}

\author{
Marina Lalremruati, Lalmuansangi C, Zothan Siama* \\ Department of Zoology, Mizoram University, Aizawl 796004, India.
}

\section{ARTICLE INFO \\ Received on: 25/07/2019 \\ Accepted on: 18/10/2019 \\ Available online: 03/12/2019}

\section{Key words:}

Mussaenda macrophylla, ABTS, antioxidants, antihemolytic, lipid peroxidation.

\begin{abstract}
This study investigates the phytochemical composition, free radical scavenging activities, and antioxidative potential of various extracts of Mussaenda macrophylla. Phytochemicals such as alkaloids, cardiac glycosides, saponins, steroids, tannins, and terpenoids were found to be present in various extracts of M. macrophylla. Aqueous extract of M. macrophylla has the highest total phenolic (387.61 $\pm 14.10 \mathrm{mg}$ gallic acid equivalent/g) and flavonoid $(5,761.65$ $\pm 38.5 \mathrm{mg}$ quercetin equivalent $/ \mathrm{g}$ ) contents. The antioxidative potential of $M$. macrophylla extracts was measured by their ability to scavenge 1,1-diphenyl-2-picrylhydrazyl (DPPH), superoxide anions $\left(\mathrm{O}_{2}{ }^{-}\right)$, and 2, $2^{\prime}$-azino-bis-(3ethylbenzothiazoline-6-sulfonic acid) (ABTS) in a cell free system. The aqueous extract of M. macrophylla possessed the highest scavenging activities for DPPH, $\mathrm{O}_{2}{ }^{-}$, and ABTS with $\mathrm{IC}_{50}$ of $25.92 \pm 0.33 \mu \mathrm{g} / \mathrm{ml}, 4.12 \pm 0.94 \mu \mathrm{g} / \mathrm{ml}$, and $17.20 \pm 0.50 \mu \mathrm{g} / \mathrm{ml}$, respectively. Furthermore, the scavenging activities of the aqueous extract of M. macrophylla against $\mathrm{ABTS}$ and $\mathrm{O}_{2}{ }^{-}$were found to be more effective than ascorbic acid which was used as standard. The total reducing power of M. macrophylla extracts was also determined by measuring the transformation of $\mathrm{Fe}^{3+}$ into $\mathrm{Fe}^{2+}$ and the methanolic extract was found to exhibit the highest reducing power. The aqueous extract of M. macrophylla showed the highest inhibitory activities against mice erythrocyte hemolysis and lipid peroxidation in the liver homogenate with an inhibition rate of $80.53 \%$ and $65.33 \%$, respectively.
\end{abstract}

\section{INTRODUCTION}

Free radicals are essential bio-regulatory molecule required for several physiological functioning of the body such as regulation of gene expression, immune response, and cellular growth (Droge, 2002; Tochhawng et al., 2013), representing an important part of aerobic life (Tiwari, 2001). However, due to their highly reactive property, over-production of the free radicals including superoxide anion radicals $\left(\mathrm{O}_{2}{ }^{-}\right)$, singlet oxygen $\left({ }^{1} \mathrm{O}_{2}\right)$, hydrogen peroxide $\left(\mathrm{H}_{2} \mathrm{O}_{2}\right)$, and hydroxyl radicals $\left({ }^{\circ} \mathrm{OH}\right)$ can hamper the body antioxidant defense systems leading to a condition called "oxidative stress". Oxidative stress is found to be closely associated with various lifestyle-related disorders

\section{*Corresponding Author}

Zothan Siama, Department of Zoology, Mizoram University, Aizawl 796004, India.E-mail: zothans@gmail.com including neurodegenerative disorders, arthritis, coronary heart disease, inflammation, diabetes, and cancer (Maxwell, 1995; Statdtman, 1992; Valko et al., 2006). Despite the presence of small antioxidant molecules (e.g., glutathione) and several antioxidant enzymes (e.g., glutathione peroxidise, glutathione reductase, catalase, superoxide dismutase) in our body, these agents are not sufficient to maintain the normal redox status during increased oxidative stress (Seifried et al., 2007). Therefore, maintenance of optimal body function and redox homeostasis in cells may require exogenous antioxidants supplementation. Medicinal plants have been used for human healthcare and represent the mainstay of traditional systems of medicine. The importance of plants as natural sources of antioxidants and free radical scavengers has been reported earlier by various researchers (Auddy et al., 2003; Poullain et al., 2004; Siama et al., 2018; Shantabi et al., 2014). Many modern drugs used for the treatment of several diseases have been isolated from different medicinal plants (Cragg and Newman, 2013). Consumption of natural antioxidants, such as 
those derived from plants, has been reported to lower the risk of cancer and many lifestyle-related disorders (Gerber et al., 2002).

Mizoram, a state in North-East India, with its rich biodiversity offers a number of medicinal plants. One such plant is Mussaenda macrophylla, a member of the Rubiaceae family, locally known as Vakep. M. macrophylla is a flowering shrub, endemic to south-east Asia, reported to occur in India, China, and Myanmar (Manandhar, 2002). Mussaenda macrophylla has been traditionally used for the treatment of various health problems such as coughs, chronic ulcer, diarrhea, dysentery, indigestion, cancers, and even for the treatment of snake bites (Rosangkima and Jagetia, 2015; Sharma et al., 2001). Among the genus Mussaenda, M. frondosa (Siju et al., 2010), M. glabrata (Menon and Sasikumar, 2011), and M. roxburghii (Aktar et al., 2014; Islam et al., 2015) have been reported to have multi-pharmaceuticals importance such as antioxidants, anti-inflammatory, and thrombolytic activity. Despite the extensive use of $M$. macrophylla as traditional medicine, there has been no scientific validation of their pharmaceutical property. Therefore, we aimed to investigate the free radical scavenging and antioxidative potentials of various solvent extracts of M. macrophylla both in vitro and ex vivo.

\section{MATERIALS AND METHODS}

\section{Chemicals}

Quercetin dihydrate, gallic acid, 2,2'-azino-bis(3-ethylbenzothiazoline-6-sulfonic acid) (ABTS), nicotinamide adenine dinucleotide, 2-deoxyribose, phenazine methosulfate, nitro blue tetrazolium (NBT), disodium hydrogen phosphate, ferric chloride, sodium nitrite, potassium persulfate, and hydrogen peroxide $\left(\mathrm{H}_{2} \mathrm{O}_{2}\right)$ were obtained from HiMedia Laboratories Pvt., Ltd. (Mumbai, India). Thiobarbituric acid and 1,1-diphenyl2-picrylhydrazyl (DPPH) radicals were obtained from Sigma Aldrich Inc (Louis, Germany). Folin-Ciocalteu's reagent, trichloroacetic acid (TCA), sodium hydroxide, sodium carbonate, ascorbic acid (ASA), and ferrous sulfate were purchased from SD fine-Chem Ltd. (Mumbai, India). Aluminum chloride and sodium dihydrogen phosphate were obtained from Merck Specialities Pvt., Ltd. (Mumbai, India). Ethylenediamine tetraacetic acid) was obtained from Qualigens Fine Chemicals (Mumbai, India). Potassium ferricyanide was purchased from Loba Chemie Pvt., Ltd. (Mumbai, India).

\section{Collection of plant and preparation of extracts}

Mussaenda macrophylla was collected from Kolasib District, Mizoram. Identification and authentication of the plant were done by the Department of Horticulture, Aromatic and Medicinal Plants, Mizoram University, Aizawl. The leaves were dried naturally in a well-ventilated and dark place at room temperature for up to 30 days and pulverized by using a mixer grinder. The dried powdered leaves were then sequentially extracted with petroleum ether, chloroform, methanol, and distilled water using the Soxhlet apparatus for a minimum of 40 cycles each. The liquid extracts were filtered and dried in a rotary evaporator (Buchi, Germany) under reduced pressure at $40^{\circ} \mathrm{C}$ for 5 hours. The extracts obtained were then collected and stored at $4^{\circ} \mathrm{C}$ until use. Henceforth, chloroform extract, methanol extract, and aqueous extract of M. macrophylla will be called as MMCE, MMME, and MMAE, respectively.

\section{Phytochemical analysis}

Preliminary phytochemical screening was performed using standard methods (Bargah, 2015; Gangwar et al., 2014; Muthukrishnan and Manogaran, 2018). Samples of different fractions of M. macrophylla were tested for the presence of cardiac glycosides, alkaloids, saponins, steroids, tannins, terpenoids, and phlobatannins. Results are expressed as $(+)$ for the presence and (-) for the absence of phytochemical.

\section{Estimation of total phenolic content}

The total phenolic content of M. macrophylla was estimated using standard method (Khan et al., 2012). Briefly, 5 $\mathrm{ml}$ of Folin-Ciocalteu's reagent (diluted ten-fold) was mixed with $1 \mathrm{ml}$ of M. macrophylla extracts $(0.25-8.0 \mathrm{mg} / \mathrm{ml})$. After 5 minutes of incubation, $4 \mathrm{ml}$ of sodium carbonate $(0.115 \mathrm{mg} / \mathrm{ml})$ was added to the mixture. The mixture was then incubated in the dark at room temperature for 2 hours and the absorbance was recorded at $765 \mathrm{~nm}$. Calibration curve was also prepared by mixing methanol solution of gallic acid $(1 \mathrm{ml}, 0.25-4.0 \mathrm{mg} / \mathrm{ml})$ with the reagents above and absorbance was recorded at $765 \mathrm{~nm}$ using an ultraviolet-Visible spectrophotometer. The experiment was repeated three times and the total phenolic content was expressed as gallic acid equivalents (GAEs) $\mathrm{mg} / \mathrm{g}$ of the dry extract.

\section{Estimation of total flavonoid content}

Total flavonoid content of various extracts of $M$. macrophylla was estimated according to the method previously described (Khan et al., 2012) with minor modifications. Briefly, $0.25 \mathrm{ml}$ of $M$. macrophylla extracts $(0.25-8.0 \mathrm{mg} / \mathrm{ml})$ and standard quercetin solution was mixed with $75 \mu \mathrm{l}$ of $5 \%(\mathrm{w} / \mathrm{v})$ sodium nitrite solution and $1.25 \mathrm{ml}$ of distilled water. After the addition of $150 \mu \mathrm{l}$ of $10 \%(\mathrm{w} / \mathrm{v})$ aluminum chloride, the solution was allowed to stand for 5 minutes followed by the addition of $0.5 \mathrm{ml}$ of $1 \mathrm{M} \mathrm{NaOH}$. The volume of the solution was made up to $2.5 \mathrm{ml}$ using distilled water and mixed well. The absorbance was recorded immediately at $510 \mathrm{~nm}$. The total flavonoid content of M. macrophylla was expressed in terms of quercetin equivalent (mg/g extract).

\section{Determination of free radical scavenging activity in vitro}

The ability of different extracts of M. macrophylla to inhibit the generation of various free radicals was carried out as described below.

\section{$D P P H$ radical scavenging activity}

The scavenging activity of $M$. macrophylla extracts for DPPH radical was determined according to Lalhminghlui and Jagetia (2018) with minor modifications. Briefly, $0.5 \mathrm{ml}$ of various extracts of $M$. macrophylla $(1-400 \mu \mathrm{g} / \mathrm{ml})$ was mixed with $1 \mathrm{ml}$ of methanol solution of $0.1 \mathrm{M}$ DPPH followed by 30 minutes incubation in the dark. The absorbance of the solution at $523 \mathrm{~nm}$ was compared with the control. The scavenging activity of the plant extract against DPPH was expressed as $\mathrm{IC}_{50}$ which is the concentration $(\mu \mathrm{g} / \mathrm{ml})$ of extract at which $50 \%$ of the DPPH radicals were inhibited. ASA was used as the standard. The test was repeated at all concentrations of each sample in triplicate. The scavenging activity was then calculated based on the percentage of DPPH radicals scavenged using the formula: 
Scavenging $(\%)=\left[\left(\mathrm{A}_{\text {blank }}-\mathrm{A}_{\text {sample }}\right) / \mathrm{A}_{\text {blank }}\right] \times 100$

Where $\mathrm{A}_{\text {blank }}$ is the absorbance of the control (solution containing all the reagents except the plant extracts) and $\mathrm{A}_{\text {sample }}$ is the absorbance of the solution containing the plant extract.

\section{Superoxide radical scavenging activity}

Superoxide scavenging activity was determined by the NBT reduction method (Lalhminghlui and Jagetia, 2018) with minor modifications. In brief, the reaction mixture was prepared using $0.2 \mathrm{ml}$ of NBT [1 $\mathrm{mg} / \mathrm{ml}$ in dimethyl sulfoxide (DMSO)] and $0.6 \mathrm{ml}$ of plant extract $(1-800 \mu \mathrm{g} / \mathrm{ml})$. Then, the volume of the mixture was made up to $2.8 \mathrm{ml}$ using $2 \mathrm{ml}$ of alkaline DMSO (1 $\mathrm{ml} \mathrm{DMSO}$ in $5 \mathrm{mM} \mathrm{NaOH}$ ). The absorbance of the mixture was recorded at $560 \mathrm{~nm}$ and pure DMSO was used as blank. ASA served as the standard and the ability of M. macrophylla extracts to scavenge the superoxide radical was calculated.

$$
\% \text { scavenging }=\left(\mathrm{A}_{\mathrm{e}}-\mathrm{A}_{\mathrm{o}} / \mathrm{A}_{\mathrm{e}}\right) \times 100
$$

Where $A_{o}$ is the absorbance without plant extract and $A_{e}$ is the absorbance with the plant extract.

\section{ABTS radical scavenging activity}

The scavenging activity of $M$. macrophylla against ABTS was determined using the method of Khan et al. (2012). Briefly, $5 \mathrm{ml}$ each of $7 \mathrm{mM}$ ABTS and $2.45 \mathrm{mM}$ potassium persulfate were mixed for a stock solution. A stock solution was then incubated at room temperature in the dark for 12 hours so as to yield a dark-colored solution that contains $\mathrm{ABTS}^{\cdot+}$ radicals. A freshly prepared working solution consists of a stock solution diluted with $50 \%$ methanol having an initial absorbance of $0.70( \pm 0.02)$ at $745 \mathrm{~nm}$. $\mathrm{ABTS}^{\circ+}$ radicals scavenging activity was then assessed by mixing $150 \mu \mathrm{l}$ of different fractions of various extracts of $M$. macrophylla $(1-200 \mu \mathrm{g} / \mathrm{ml})$ with $1.5 \mathrm{ml}$ of ABTS working solution. The decrease in absorbance was measured immediately at $745 \mathrm{~nm}$. The test was repeated at all concentrations of each sample in triplicate. ASA served as the standard. The scavenging activity of the plant extract was then calculated using the formula:

$$
\text { Scavenging }(\%)=\left[\left(\mathrm{A}_{\text {blank }}-\mathrm{A}_{\text {sample }}\right) / \mathrm{A}_{\text {blank }}\right] \times 100
$$

Where $\mathrm{A}_{\text {blank }}$ is the absorbance of the control (solution containing all the reagents except the plant extracts) and $\mathrm{A}_{\text {sample }}$ is the absorbance of the solution containing the plant extract.

\section{Reducing power}

The reducing power of $M$. macrophylla extracts was estimated using the method given by Adjimani and Asare (2015) with minor modifications. Briefly, $2.5 \mathrm{ml}$ each of $0.2 \mathrm{M}$ phosphate buffer $(\mathrm{pH}-6.6)$ and $1 \%$ potassium ferricyanide solution were mixed with $M$. macrophylla extracts (1-400 $\mu \mathrm{g} / \mathrm{ml}$; dissolved in their respective solvent). After incubation of the mixture at $50^{\circ} \mathrm{C}$ for 20 minutes, $2.5 \mathrm{ml}$ of $10 \%$ TCA was added. The mixture was then centrifuged at $3,000 \mathrm{rpm}$ for 10 minutes. Equal volume of distilled water was added to the supernatant followed by $0.5 \mathrm{ml}$ of $1 \%$ ferric chloride solution. Absorbance of the mixture was measured at $700 \mathrm{~nm}$. The increase in absorbance indicated increasing reducing power of the extract.

\section{Ex vivo antioxidant assay}

\section{Anti-hemolytic activity}

The inhibition of mice erythrocyte hemolysis by various extracts of M. macrophylla was measured to determine their antioxidative potential (Zhou et al., 2014). Blood was collected from Swiss albino mice of the same age group (10-12 w) and body weights (25-27 g) by heart puncture in a heparinized tube. The mice erythrocyte hemolysis was induced with $\mathrm{H}_{2} \mathrm{O}_{2}$ that serve as a free radical initiator. A mixture was prepared by adding 0.5 $\mathrm{ml}$ of $5 \%(\mathrm{v} / \mathrm{v})$ suspension of red blood cells (RBC) in phosphate buffered saline (PBS), $0.4 \mathrm{ml}(0.5 \mathrm{mg} / \mathrm{ml})$ of different extracts of M. macrophylla, and $100 \mu \mathrm{l}$ of $1 \mathrm{~mol} / \mathrm{L} \mathrm{H}_{2} \mathrm{O}_{2}$. The reaction mixture was gently mixed while being incubated at $37^{\circ} \mathrm{C}$ for 3 hours. It was then diluted with $4 \mathrm{ml}$ of PBS and centrifuged at 2,000 rpm for 10 minutes. The supernatant was collected and absorbance was recorded at $540 \mathrm{~nm}$. The rate of inhibition of erythrocyte hemolysis was then calculated.

$$
\text { Inhibition rate }(\%)=\left[1-(\mathrm{A} 1-\mathrm{A} 2) / \mathrm{A}_{0}\right] \times 100
$$

Where $\mathrm{A}_{0}$ is the absorbance of the control, $\mathrm{A} 1$ is the absorbance of the solution containing the plant extract, and A2 is the absorbance without RBC.

\section{Inhibition of lipid peroxidation}

Lipid peroxidation inhibitory potential of $M$. macrophylla extracts was measured according to the method given by Rajinder et al. (2010) using mice liver. The liver was excised from Swiss albino mice and $1 \%$ liver homogenate was prepared and centrifuged at $3,000 \mathrm{rpm}$ at $4^{\circ} \mathrm{C}$ for 10 minutes. $0.5 \mathrm{ml}$ of supernatant was mixed with $0.5 \mathrm{ml}(0.5 \mathrm{mg} / \mathrm{ml})$ of $M$. macrophylla extracts, $0.25 \mathrm{ml}$ each of $0.5 \mathrm{~mol} / \mathrm{L} \mathrm{FeCl}_{2}$ and $\mathrm{H}_{2} \mathrm{O}_{2}$, and incubated at $37^{\circ} \mathrm{C}$ for 1 hour. Absorbance was measured at $535 \mathrm{~nm}$ and the rate of inhibition of lipid peroxidation was calculated using the formula:

$$
\text { Inhibition rate }(\%)=\left[1-(\mathrm{A} 1-\mathrm{A} 2) / \mathrm{A}_{0}\right] \times 100
$$

Where $\mathrm{A}_{0}$ is the absorbance of the control, A1 is the absorbance of the solution containing the plant extract, and A2 is the absorbance without liver homogenate.

\section{Animals}

Colony of inbred Swiss albino mice is being maintained under standard environmental conditions of temperature $\left(22^{\circ} \mathrm{C} \pm\right.$ $5^{\circ} \mathrm{C}$ ) and light (12 hours of light and dark, respectively) (Frontier Euro Digital Timer, Taiwan) at the Animal House, Department of Zoology, Mizoram University, India. The animals were having free access to food and water. Caring and handling of animals were carried out based on the guidelines given by WHO, Geneva, Switzerland. The study was approved by the Institutional Animal Ethical Committee, Mizoram University, India (No. MZUIAEC/2018/09) and CPCSEA, New Delhi, India (Registration No. 1999/GO/ReBi/S/18/CPCSEA).

\section{Statistical analysis}

Results are expressed as mean \pm standard error of mean. One-way analysis of variance was performed to test the significant variations on phytochemical contents and the antioxidative potential of various extracts followed by Tukey 
multiple comparisons of means. The $\mathrm{IC}_{50}$ values were calculated by plotting the $\%$ inhibition of free radicals against the log doses using GraphPad Prism software version 6.0. A $p$-value of less than 0.05 was considered statistically significant.

\section{RESULTS AND DISCUSSION}

\section{Phytochemical analysis}

The present study revealed the presence of various naturally occurring compounds such as alkaloids, cardiac glycosides, saponins, steroids, tannins, and terpenoids in $M$. macrophylla extracts (Table 1). However, different solvent extracts of $M$. macrophylla contain different phytochemicals. These compounds, belonging to the polyphenolic group, have been reported to exhibited several pharmaceutical potentials. For example, tannins as anti-oxidants and anti-inflammatory (Dolara et al., 2005), alkaloids as anti-hypertensive and anti-malarial (Wink et al., 1998), terpenoids as anti-ulcer and anti-microbial (Cowan, 1999; Dudareva et al., 2004), and saponins as antimicrobial and anti-inflammatory (Gangwar et al., 2014; LacailleDubois and Wagner, 2000).

\section{Total phenolic and flavonoid contents}

The total phenolic content of M. macrophylla extracts increased in a concentration-dependent manner (Fig. 1). The total phenolic content showed significant variation between different extracts of M. macrophylla $\left(\mathrm{F}_{2,6}=252.14 ; p<0.001\right)$. MMAE has the highest $(p<0.001)$ total phenolic content $(387.61$ $\pm 14.10 \mathrm{mg}$ GAE$/ \mathrm{g})$ followed by MMME $(301.29 \pm 21.73 \mathrm{mg}$ $\mathrm{GAE} / \mathrm{g})$ and MMCE $(226.9 \pm 21.04 \mathrm{mg} \mathrm{GAE} / \mathrm{g})$. Similarly, dosedependent increase in the total flavonoid content was observed among the various extracts of M. macrophylla (Fig. 2). At $8 \mathrm{mg} /$ $\mathrm{ml}$, there was a significant variation $\left(\mathrm{F}_{2,6}=1,189.4 ; p<0.001\right)$ in the flavonoid contents among M. macrophylla extracts. MMAE has the highest flavonoid content $(5,761.65 \pm 38.5 \mathrm{mg}$ quercetin equivalent/g) followed by $\mathrm{MMME}(4,864.68 \pm 36.75$ $\mathrm{mg}$ quercetin equivalent/g) and MMCE $(4,830.09 \pm 32.80 \mathrm{mg}$ quercetin equivalent/g). The present study indicated the presence of significant amounts of flavonoid and phenolic compounds in

Table 1. Preliminary phytochemical screening of different extracts of M. macrophylla. ("+" indicates presence of phytochemical and "-" indicates absence of phytochemical).

\begin{tabular}{|c|c|c|c|c|c|}
\hline Phytochemicals & Reagent & $\begin{array}{l}\text { Colour } \\
\text { Indication }\end{array}$ & MMCE & MMME & MMAE \\
\hline Alkaloids & $\begin{array}{l}\text { Dragendorff's } \\
\text { reagent }\end{array}$ & $\begin{array}{l}\text { Reddish brown } \\
\text { precipitate }\end{array}$ & - & + & + \\
\hline \multirow[t]{3}{*}{$\begin{array}{l}\text { Cardiac } \\
\text { glycosides }\end{array}$} & $\begin{array}{l}\text { Glacial acetic } \\
\text { acid }\end{array}$ & & & & \\
\hline & Ferric chloride & Brown ring & - & + & + \\
\hline & Sulphuric acid & & & & \\
\hline Saponins & Olive oil & $\begin{array}{l}\text { Whitish } \\
\text { emulsion }\end{array}$ & - & + & + \\
\hline Steroids & Sulphuric acid & Red colour & - & + & - \\
\hline Tannins & Ferric chloride & $\begin{array}{l}\text { Brownish green } \\
\text { or blue-black }\end{array}$ & + & - & + \\
\hline Terpenoids & Sulfuric acid & Reddish Brown & - & + & - \\
\hline Phlobatannins & $\begin{array}{l}\text { Hydrochloric } \\
\text { acid }\end{array}$ & Red precipitate & - & - & - \\
\hline
\end{tabular}

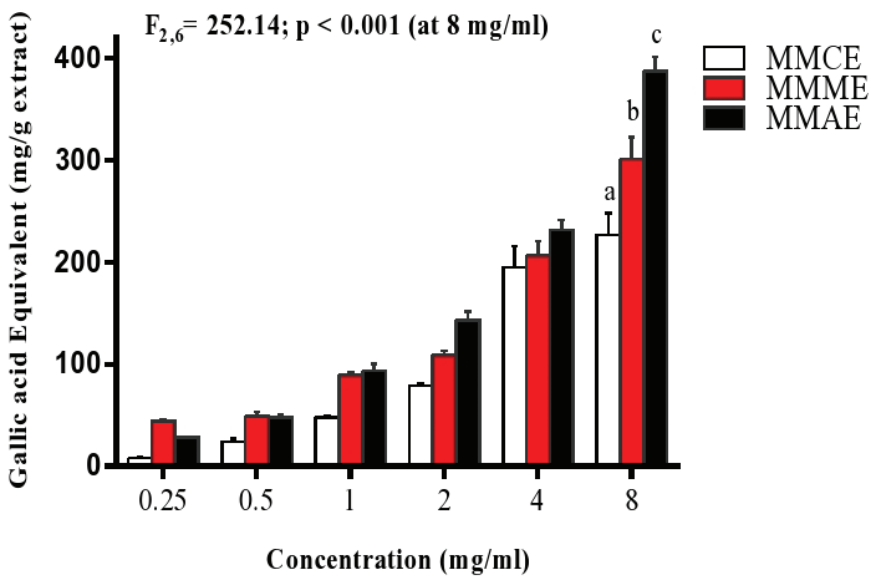

Figure 1. Total phenolic content of various extracts of $M$. macrophylla determined as GAE. Values are expressed as mean \pm standard error mean (SEM), $n=3$. Different letters indicate significant variation.

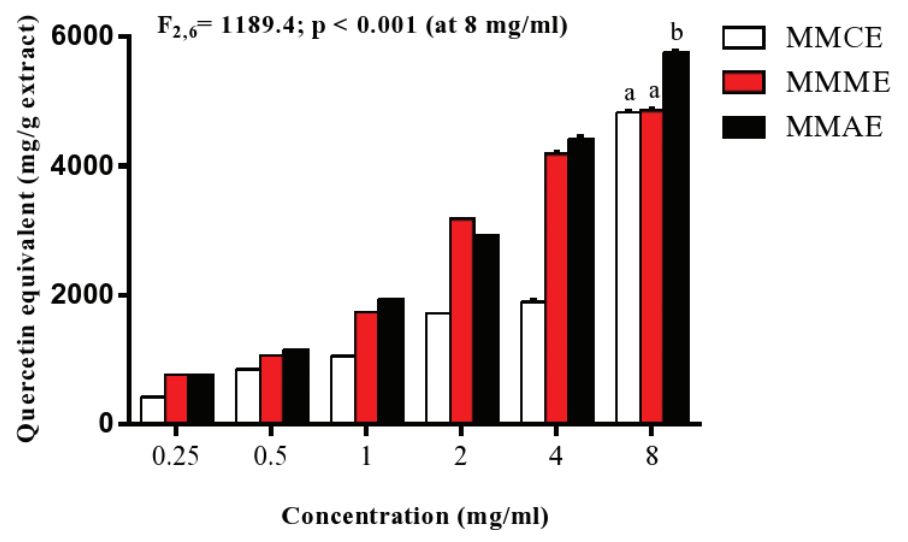

Figure 2. Total flavonoid content of various extracts of M. macrophylla determined as quercetin equivalent. Values are expressed as mean $\pm \mathrm{SEM}, n=3$. Different letters indicate significant variation.

M. macrophylla extracts. The phenolic compounds have been reported to have anti-oxidants property due to their conjugated ring structures and the presence of hydroxyl groups. Their scavenging activity is mostly achieved by hydrogenation and can even stabilize free radicals by complexing with oxidizing species (Amic et al., 2003; Diplock, 1997). Compounds containing phenols have been reported to exhibit cardio-protective, hepatoprotective, anti-allergenic, anti-inflammatory, anti-microbial, antithrombotic, anti-atherogenic, and vaso-dilatory effects (Alpinar et al., 2009; Middleton et al., 2000; Siama et al., 2018). Similarly, flavonoids are having antioxidants, free radical scavenging, antiinflammatory, metal chelating, and lipid peroxidation inhibitory properties due to their unique structural conformations (Cook and Samman, 1996). Due to their scavenging or chelating activities, flavonoids have been reported to serve as healthpromoting compound (Havsteen, 1983) and protect humans against several diseases like atherogenesis, carcinogenesis, hepatotoxicity, and thrombosis (Tiwari, 2001). Flavonoids such as Aureusidin-4-glucoside, Aureusidin-6-glucoside, Aureusidin4,6-diglucoside, and Cernuoside have been isolated from $M$. hirsutissima (Harborne and Girija, 1983). Quercetin and hypenin were also reported to occur in M. frondosa (Lakshmi et al., 1985). 
The root bark of $M$. macrophylla has been reported to contain triterpenoid glycosides including 3-O- $\beta$-D-glucopyranosyl-28-O$\alpha$-L-rhamnopyranosyl-16 $\alpha$-hydroxy-23-deoxy-protobassic acid, 28-O- $\beta$-D-glucopyranosyl-16 $\alpha$-hydroxy-23-deoxyprotobassic acid, 3-O- $\beta$-D-glucopyranosyl-28-O- $\alpha$-L-rhamnopyranosyl$16 \alpha$-hydroxyprotobassic acid, 3-O-acetyloleanolic acid, and 3-O-acetyldaturadiol. The triterpenoid glycosides isolated from $M$. macrophylla were reported to exhibit inhibitory action against Porphyromonas gingivalis (Kim et al., 1999), Salmonella paratyphi, and Aspergillus niger (Chowdhury et al., 2013).

\section{In vitro free radical scavenging activities of $\mathrm{M}$. macrophylla}

\section{DPPH radical scavenging activity}

The methanolic and aqueous extracts of M. macrophylla showed a dose-dependent increase in DPPH radicals scavenging activity as indicated by the discoloration of DPPH. Maximum scavenging activity for both methanolic and aqueous extracts was observed at a concentration of $400 \mu \mathrm{g} / \mathrm{ml}$. Log-doses of various extracts of $M$. macrophylla and standard ASA were plotted against DPPH inhibition (\%) for the calculation of $\mathrm{IC}_{50}$ (Fig. 3). The aqueous extract $\left(\mathrm{IC}_{50}: 25.92 \pm 0.33 \mu \mathrm{g} / \mathrm{ml}\right)$ and methanolic extract $\left(\mathrm{IC}_{50}: 26.43 \pm 0.55 \mu \mathrm{g} / \mathrm{ml}\right)$ were found to have similar DPPH radical scavenging activity (Fig. 4), whereas the $\mathrm{IC}_{50}$ of chloroform extract could not be determined within the given concentration.

The antioxidant property of natural compounds such as plant extracts can be evaluated through their ability to reduced methanolic DPPH solution to non-radical form DPPH-H. The antioxidative potential of $M$. macrophylla extracts was determined by their ability to scavenge DPPH radicals, and M. macrophylla extracts were found to be active radical scavengers. Compounds such as polyhydroxyl aromatic compounds, cysteine, tocopherol, glutathione, and ASA have been known to have the ability to reduce DPPH by hydrogenation (Blois, 1958; Moon et al., 2010). Among the genus Mussaenda, M. frondosa (Siju et al., 2010), M. glabrata (Menon and Sasikumar, 2011), and M. roxburghii (Islam et al., 2015) have been reported to effectively scavenge the DPPH radicals.

\section{Scavenging activity of superoxide radical}

Various extracts of M. macrophylla showed a dosedependent increase in inhibition of superoxide radical $\left(\mathrm{O}_{2}{ }^{-}\right)$ generation. Maximum $\mathrm{O}_{2}{ }^{-}$scavenging activity was recorded at

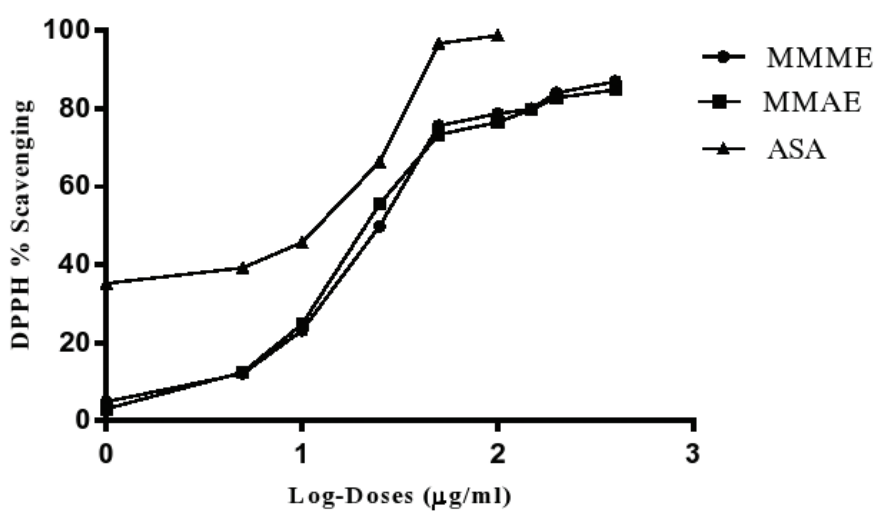

Figure 3. Plot of log-doses of various extracts of M. macrophylla and standard ASA against DPPH inhibition (\%) for the calculation of $\mathrm{IC}_{50}$.
$400 \mu \mathrm{g} / \mathrm{ml}$ in all the extracts of $M$. macrophylla. Figure 5 represents the plot of Log-doses of various extracts of M. macrophylla and standard ASA against $\mathrm{O}_{2}{ }^{-}{ }^{-}$scavenging activity for the calculation of $\mathrm{IC}_{50}$. Aqueous extract possessed the highest scavenging activity $\left(\mathrm{IC}_{50} ; 4.12 \pm 0.94 \mu \mathrm{g} / \mathrm{ml}\right)$ followed by methanolic extract $\left(\mathrm{IC}_{50}\right.$; $7.83 \pm 1.2 \mu \mathrm{g} / \mathrm{ml})$ and chloroform extract $\left(\mathrm{IC}_{50} ; 40.24 \pm 3.5 \mu \mathrm{g} /\right.$ $\mathrm{ml})$. The $\mathrm{O}_{2}{ }^{\bullet}$ scavenging activity of MMAE was even better than the ASA $\left(\mathrm{IC}_{50} ; 8.65 \pm 1.6 \mu \mathrm{g} / \mathrm{ml}\right.$ ) (Fig. 6).

Superoxide anion radical, a highly reactive free radical, leads to cellular damage by initiating lipid oxidation indirectly (Aruoma and Halliwell, 1987). Superoxide $\left(\mathrm{O}_{2}{ }^{-}\right)$radical can break down to form stronger reactive oxygen species (ROS) including hydroxyl radicals and singlet oxygen. Thus, scavenging of $\mathrm{O}_{2} \bullet^{-}$could result in inhibition of other ROS generation and protect the cells from oxidative damage. The present study suggest that $\mathrm{O}_{2}{ }^{-}$radical scavenging activity of $M$. macrophylla extracts increased with increases in concentration and the aqueous extract of $M$. macrophylla showed higher scavenging potential than the standard ASA. The $\mathrm{O}_{2}{ }^{--}$scavenging activity of M. macrophylla extracts could be attributed to their flavonoids contents (Robak and Gryglewski, 1988).

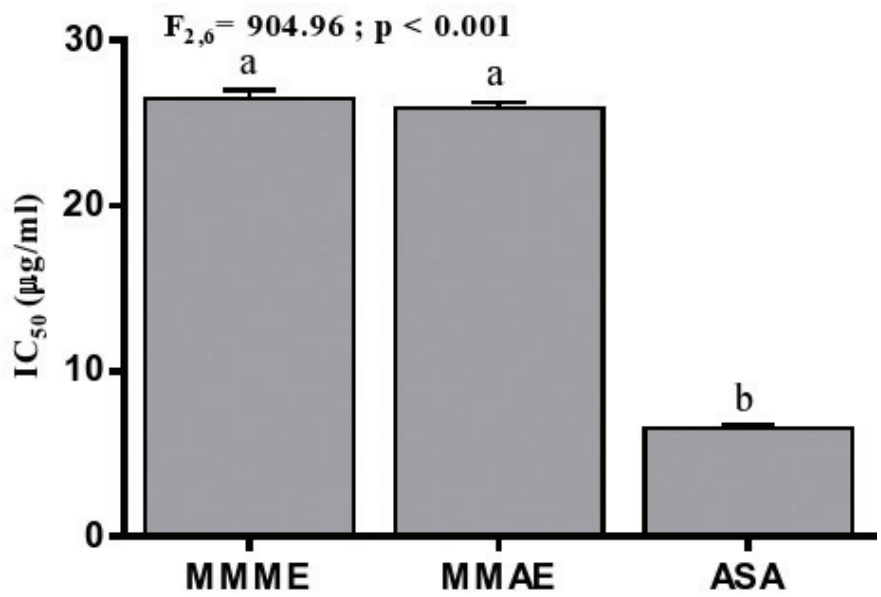

Figure 4. $\mathrm{IC}_{50}(\mu \mathrm{g} / \mathrm{ml})$ for DPPH of various extracts of M. macrophylla and standard ASA. Values are expressed as mean $\pm \mathrm{SEM}, n=3$. Different letters indicate significant variation.

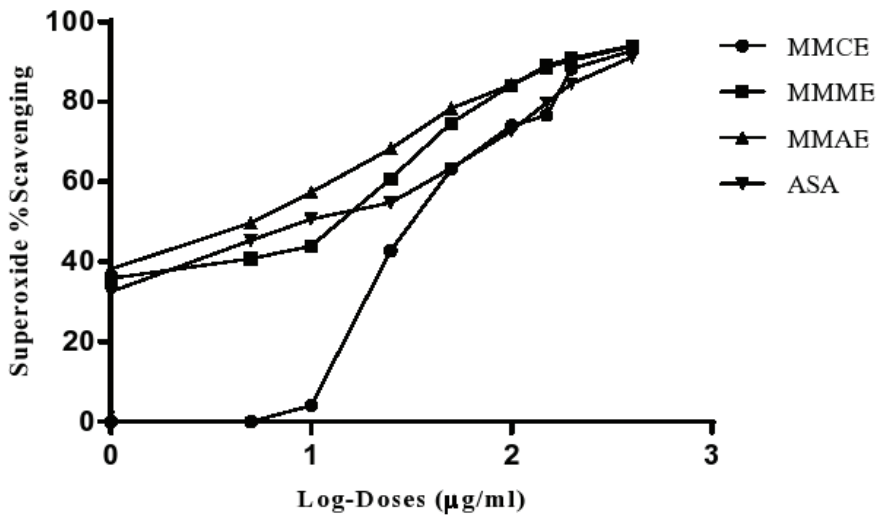

Figure 5. Plot of log-doses of various extracts of M. macrophylla and standard ASA against superoxide radical inhibition (\%) for the calculation of $\mathrm{IC}_{50}$. 
ABTS radical scavenging activity

$\mathrm{ABTS}^{\bullet+}$ radical scavenging property of $M$. macrophylla extracts increased in a concentration-dependent manner as indicated by dis-coloration of the $\mathrm{ABTS}^{\bullet+}$. Maximum scavenging activity was recorded at $200 \mu \mathrm{g} / \mathrm{ml}$ for all the extracts of M. macrophylla. Log-doses of various extracts of $M$. macrophylla and standard ASA were plotted against $\mathrm{ABTS}^{\bullet+}$ inhibition (\%) for the calculation of $\mathrm{IC}_{50}$ (Fig. 7). MMAE possessed the highest scavenging activity (lowest $\mathrm{IC}_{50} ; 17.20 \pm 1.5 \mu \mathrm{g} / \mathrm{ml}$ ) followed by MMME $\left(\mathrm{IC}_{50} ; 25.95\right.$ $\pm 1.8 \mu \mathrm{g} / \mathrm{ml})$ and $\mathrm{MMCE}\left(\mathrm{IC}_{50} ; 197.16 \pm 5.5 \mu \mathrm{g} / \mathrm{ml}\right)$. The aqueous and methanolic extracts of $M$. macrophylla were found to be more effective in scavenging $\mathrm{ABTS}^{\bullet+}$ radical than the standard ASA $\left(\mathrm{IC}_{50} ; 39.70 \pm 1.2 \mu \mathrm{g} / \mathrm{ml}\right.$ ) (Fig. 8). There was significant positive correlation between phenol $\left(r^{2}=1.00 ; p<0.001\right)$ and flavonoid $\left(r^{2}=0.99 ; p<0.001\right)$ contents of $M$. macrophylla extracts and their free radicals (DPPH, $\mathrm{O}_{2}{ }^{-}$and ABTS) scavenging activities.

The antioxidative activity of various extracts of $M$. macrophylla was also determined by measuring their ability to convert the blue colored $\mathrm{ABTS}^{\bullet+}$, which is formed by the interaction of ABTS and potassium ferricyanide, to ABTS. The effectiveness of this conversion depends on a number of characteristics such as an abundance of aromatic rings, types of hydroxyl group's substitution, and the molecular weight of phenolic compounds (Hagerman et al., 1998). The study demonstrates M. macrophylla extracts as potent antioxidants and their $\mathrm{ABTS}^{\circ+}$ scavenging activity could be due to their phenolic contents.

\section{Reducing power}

The reducing power of various extracts of $M$. macrophylla was determined by measuring the transformation of $\mathrm{Fe}^{3+}$ to $\mathrm{Fe}^{2+}$. The reducing activity of $M$. macrophylla extracts increased in a dose-dependent manner (Fig. 9). At $400 \mu \mathrm{g} / \mathrm{ml}$, the highest reducing activity was recorded for MMME $(1.098 \pm$ $0.0003)$ followed by MMAE $(0.731 \pm 0.002)$ and MMCE $(0.527$ $\pm 0.0008)$. The reducing activity of MMME was higher than the standard ASA $(0.87 \pm 0.02)$.

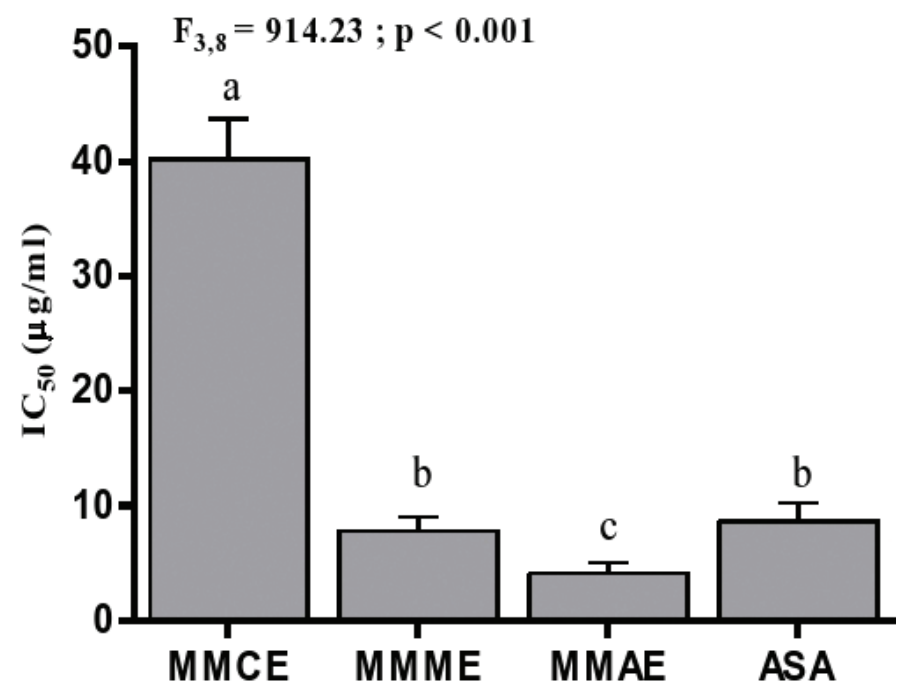

Figure 6. $\mathrm{IC}_{50}(\mu \mathrm{g} / \mathrm{ml})$ for superoxide radical of various extracts of $M$. macrophylla and standard ASA. Values are expressed as mean $\pm \mathrm{SEM}, n=3$. Different letters indicate significant variation.

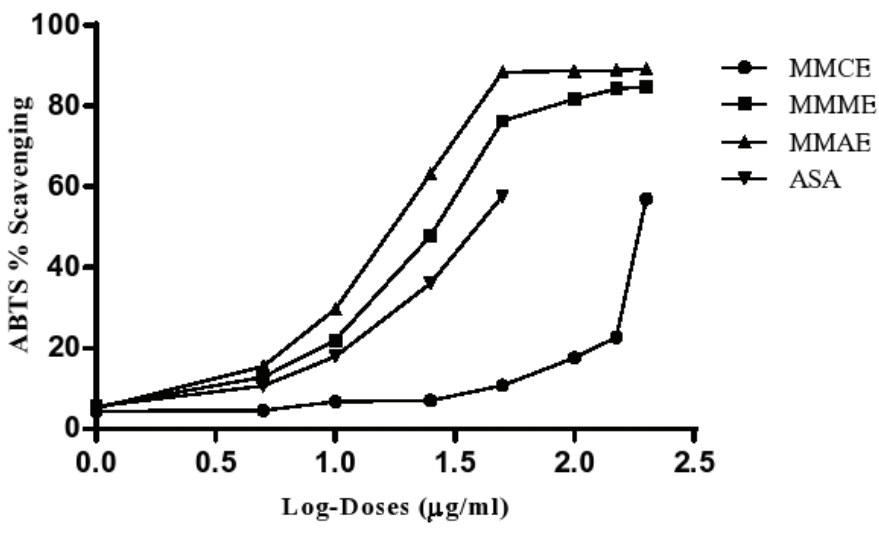

Figure 7. Plot of log-doses of various extracts of M. macrophylla and standard ASA against ABTS inhibition (\%) for the calculation of $\mathrm{IC}_{50}$.

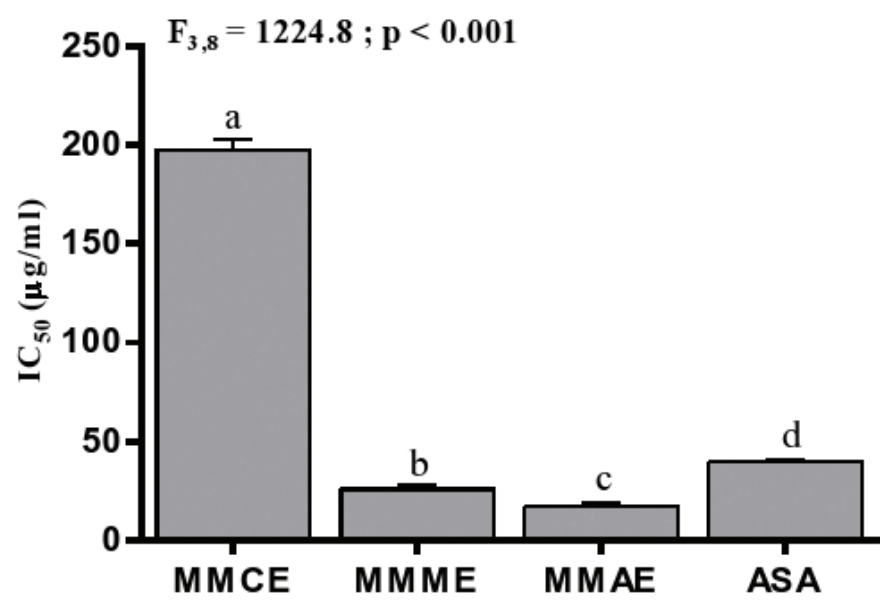

Figure 8. $\mathrm{IC}_{50}(\mu \mathrm{g} / \mathrm{ml})$ for ABTS of various extracts of $M$. macrophylla and standard ASA. Values are expressed as mean $\pm \mathrm{SEM}, n=3$. Different letters indicate significant variation.

The reducing power of compounds serves as an indicator of their antioxidant property (Meir et al., 1995). The higher absorbance at higher concentrations showed the high reducing power potential of the extracts. The reducing activity of MMME being higher than the standard ASA indicates the strong redox potential of the extract. The graded increase in percentage inhibition as the concentration of the plant extracts increases indicates that percentage scavenging effectiveness strongly depends on the extracts concentrations.

\section{Ex vivo antioxidant assay}

\section{Anti-hemolytic activity and lipid peroxidation inhibition}

The anti-hemolytic activity was determined using $0.5 \mathrm{mg} / \mathrm{ml}$ of various extracts of $M$. macrophylla. There was a significant variation in the anti-hemolytic activity of different extracts of $M$. macrophylla $\left(\mathrm{F}_{2,6}=7.19 ; p<0.05\right)$. MMAE showed the highest $(p<0.05)$ inhibitory activity against erythrocyte hemolysis with an inhibition rate of $80.53 \%$ followed by MMCE (70.91\%) and MMME (69.17\%) (Fig. 10). The lipid peroxidation inhibition potential of $M$. macrophylla extracts was also estimated in mice liver homogenate. Significant variation was observed 


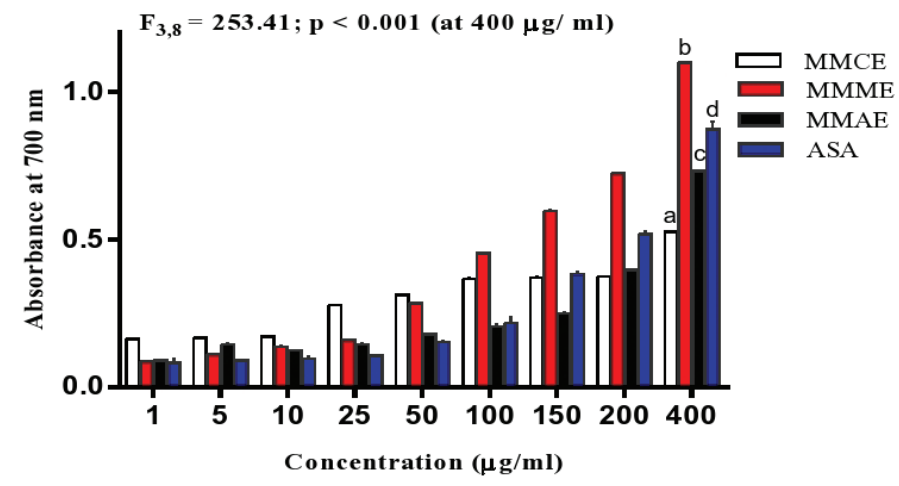

Figure 9. Reducing power of various extracts of $M$. macrophylla and standard ASA. Values are expressed as mean $\pm \mathrm{SEM}, n=3$. Different letters indicate significant variation.

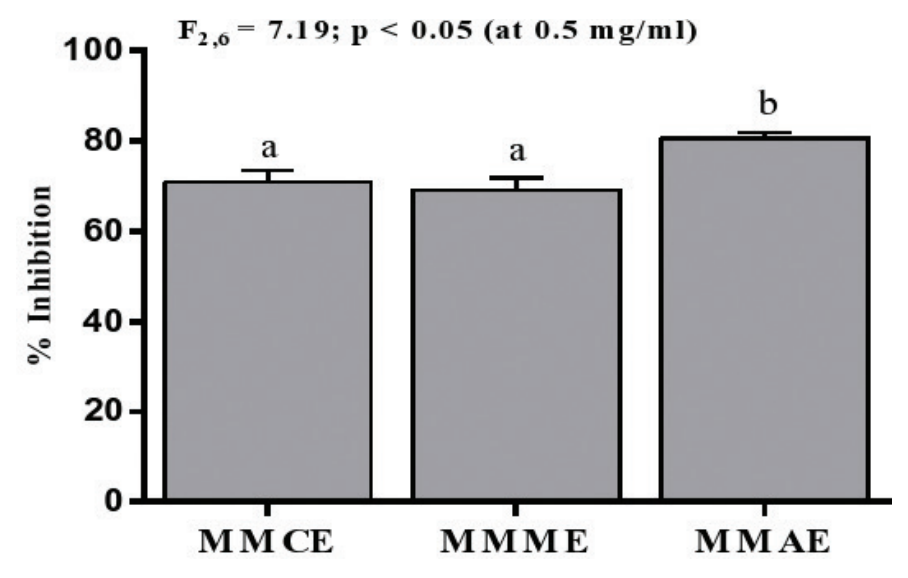

Figure 10. Anti-hemolytic activity of various extracts of M. macrophylla. Values are expressed as mean $\pm \mathrm{SEM}, n=3$. Different letters indicate significant variation.

among $M$. macrophylla extracts in their inhibitory activity against lipid peroxidation $\left(\mathrm{F}_{2,6}=8,342.13 ; p<0.001\right)$. Highest inhibitory activity was recorded for MMAE with an inhibition rate of $65.33 \%$ followed by MMME (54.38\%) and MMCE (Fig. 11).

Hemolysis occurs due to membrane damage caused by the activity of free radicals on erythrocytes that are the major target of free radicals (Ebrahimzadeh et al., 2009; Wang and Yao, 2005). Peroxidation of lipid moieties such as polyunsaturated fatty acids by a chain reaction of free radicals can lead to membrane damage (Klauning et al., 1998). Lipid peroxidation in mice liver homogenate was induced by $\mathrm{FeCl}_{2}$ $\mathrm{H}_{2} \mathrm{O}_{2}$. The formation of malonaldehyde is used as an indicator of lipid peroxidation, and subsequently oxidative stress. Various extracts of M. macrophylla showed significant anti-hemolytic and lipid peroxidation inhibition potential which could be due to the presence of numerous amounts of phenols and flavonoids. Certain phenolic compounds have been reported to partition in the cell membrane, hindering the diffusion of free radicals and consequently decreased the chain reaction of free radicals (Singh and Rajini, 2008). Flavonoids have been reported to inhibit lipid peroxidation in the erythrocytes membrane and improved their integrity against lyses by binding to the membrane (Chaudhuri et al., 2007).

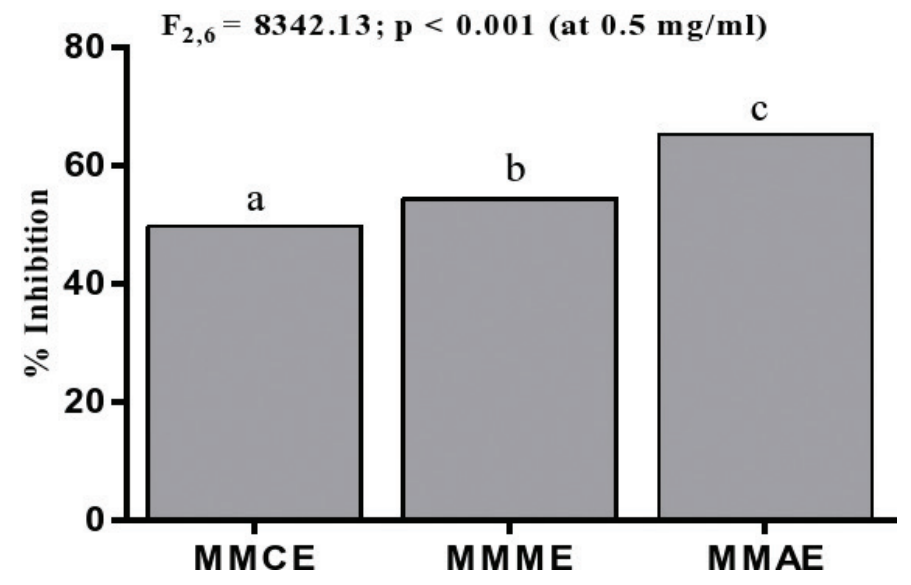

Figure 11. The lipid peroxidation inhibitory activity of various extracts of $M$. macrophylla. Values are expressed as mean $\pm \mathrm{SEM}, n=3$. Different letters indicate significant variation.

\section{CONCLUSION}

The present study indicated that $M$. macrophylla extracts possess strong antiradical and antioxidant properties. The presence of significant amounts of flavonoid and phenolic compounds in the plant might be the cause of antioxidant activities as a significant positive correlation was observed between phytochemical contents and the free radicals scavenging activity. Although the mechanism is still unclear, the protective effects of M. macrophylla extracts against hemolysis and lipid peroxidation may be attributed due to the presence of various polyphenolic compounds. However, the exact phytochemical constituent responsible for radical scavenging activity and antioxidative potential of the plant needs to be investigated further.

\section{ACKNOWLEDGMENTS}

We thank the University Grant Commission, Ministry of Tribal Affairs, Government of India, for providing fellowship to Marina Lalremruati (UGC-MZU Fellowship) and C. Lalmuansangi (201718-NFST-MIZ-00902). This work was funded by the Directorate of Science and Technology, Government of Mizoram vide grant number B. 13012/1/217/DST.

\section{CONFLICT OF INTEREST}

The authors declare no conflict of interest.

\section{REFERENCES}

Adjimani JP, Asare P. Antioxidant and free radical scavenging activity of iron chelators. Toxicol Rep, 2015; 2:721-8.

Aktar R, Uddin SJ, Grice ID, Tiralongo E. Cytotoxic activity screening of Bangladeshi medicinal plant extracts. J Nat Med, 2014; 68:246-52.

Alpinar K, Ozyurek M, Kolak U, Guclu K, Aras C, Altun M, Celik SE, Berker KI, Bektasoglu B, Apak R. Antioxidant capacities of some food plants wildly grown in Ayvalik of Turkey. Food Sci Technol Res, 2009; 15:59-64.

Amic D, Davidovic-Amic D, Beslo D, Trinajstic N. Structureradical scavenging activity relationships of flavonoids. Croatica Chemica Acta, 2003; 76:55-61.

Aruoma OI, Halliwell B. Action of hypochlorous acid on the antioxidant protective enzymes superoxide dismutase, catalase and glutathione peroxidase. Biochem J, 1987; 248(3):973-6. 
Auddy B, Ferreira M, Blasina F, Lafon L, Arredondo F, Dajas F, Tripathi PC, Seal T, Mukherjee B. Screening of antioxidant activity of three Indian medicinal plants, traditionally used for the management of neurodegenerative diseases. J Ethnopharmocol, 2003; 84(2-3):131-8.

Bargah RK. Preliminary test of phytochemical screening of crude ethanolic and aqueous extract of Moringaptery gosperma Gaertn. J Pharmacogn Phytochem, 2015; 4(1):7-9.

Blois MS. Antioxidant determinations by the use of a stable free radical. Nature, 1958; 181:1199-200.

Chaudhuri S, Banerjee A, Basu K, Sengupta B, Sengupta PK. Interaction of flavonoids with red blood cell membrane lipids and proteins: Antioxidant and antihemolytic effects. Int J Biol Macromol, 2007; 41(1):42-8.

Chowdhury SR, Akter S, Sharmin T, Islam F, Quadery TM. Antimicrobial activity of five medicinal plants of Bangladesh. J Pharmacog Phytochem, 2013, 2(1):164-70.

Cook NC, Samman S. Flavonoids-chemistry, metabolism, cardioprotective effects and dietary sources. J Nutr Biochem, 1996; 7(2):66-76.

Cowan MM. Plant products as antimicrobial agents. Clin Microbiol Rev, 1999; 12(4):564-82.

Cragg GM, Newman DJ. Natural products: a continuing source of novel drugs leads. Biochimica et Biophysica Acta, 2013; 1830:3670-95.

Diplock AT. Will the "good fairies" please prove to us that vitamin E lessens human degenerative disease. Free Radic Res, 1997; 26(6):565-83.

Dolara P, Luceri C, De Filippo C, Femia AP, Giovanneli L, Caderni C, Silvi S, Orpianesi C, Cresci A. Red wine polyphenols influence carcinogenesis, intestinal microflora, oxidative damage and gene expression profiles of colonic mucosa in F344 rats. Mutat Res, 2005; 591(1-2):237-46.

Droge W. Free radicals in the physiological control of cell function. Physiol Rev, 2002; 82(1): 47-95.

Dudareva N, Pichersky E, Gershenzon J. Biochemistry of plant volatiles. Plant Physiol, 2004; 135(4):1893-902.

Ebrahimzadeh MA, Ehsanifer S, Eslami B. Sambucusebuluselburensis fruits: a good source for antioxidants. Pharmacogn Mag, 2009; 4(9):213-8.

Gangwar M, Gautam MK, Sharma AK, Tripathi YB, Goel RK, Nath G. Antioxidant capacity and radical scavenging effect of polyphenil rich Mallotus philippenensis fruit extract on human erythrocytes: an in vitro study. Sci World J, 2014:1-12.

Gerber M, Boutron-Ruault MC, Herchberg S, Riboli E, Scalbert A, Seiss MH. Food and cancer: state of the art about the protective effect of fruits and vegetables. B Cancer, 2002; 89(3):293-312.

Hagerman AE, Reidl KM, Jones GA, Sovik KN, Ritchard NT, Hartzfeld PW. High molecular weight plant polyphenolics (tannins) as biological antioxidants. J Agr Food Chem, 1998; 46:1887-92.

Harborne JB, Girija AR, Maheswari Devi H, Lakshmi NKM. Anthochlor pigments from the petals of Mussaenda hirsutissima and Zinnia linearis. Phytochemistry, 1983; 22(12):2741-2. Havsteen B. Flavonoids, a class of natural products of high pharmacological potency. Biochem Pharmacol, 1983; 32(7):1141-8.

Islam F, Raihan O, Chowdhury D, Khatun M, Zuberi N, Khatun L, Brishti A, Bahar E. Apoptotic and antioxidant activities of methanol extract of Mussaenda roxburghiileaves. Pak J Pharm Sci, 2015; 28:2027-34.

Khan RA, Khan MR, Sahreen S, Ahmed M. Evaluation of phenolic contents and antioxidant activity of various solvent extracts of Sonchus asper (L). Hill Chem Cent J, 2012; 6:12-8.

Kim NC, Desjardins AE, Wu CD, Kinghorn AD. Activity of triterpenoid glycosides from the root bark of Mussaenda macrophylla against two oral pathogens. J Nat Prod, 1999; 62:1379-84.

Klauning JE, Xu Y, Isenberg JS, Bachowski S, Kolaja KL, Jiang $\mathrm{J}$. The role of oxidative stress in chemical carcinogenesis. Environ Health Perspect, 1998; 106:289-95.

Lacaille-Dubois MA, Wagner H. Bioactive saponins from plants: an update. Stud Nat Prod Chem, 2000; 21(B):633-87.
Lakshmi DKM, Girija AR, Rao DV, Rao EV. Studies on the isolation and characterization of flavones and triterpenoids from a few plants. Indian J Pharm Sci, 1985, 47:122-8.

Lalhminghlui K, Jagetia GC. Evaluation of the free-radical scavengingand antioxidant activities of Chilauni, Schima wallichii Korth in vitro. Future Sci OA, 2018, 4(2):272-83.

Manandhar NP. Plants and people of Nepal. J Ethnobiol, 2002; 23(2):313-4.

Maxwell SR. Prospects for the use of antioxidant therapies. Drugs, 1995; 49(3):345-61.

Meir S, Kanner J, Akiri B, Hadas SPJ. Determination and involvement of aqueous reducing compounds in oxidative defense systems of various senescing leaves. J Agr Food Chem, 1995; 43:1813-9.

Menon DB, Sasikumar JM. Antioxidant and anti-inflammatory activities of the root of Mussaenda glabrata. Int J Pharm Tech Res, 2011; 4(10):3320-2.

Middleton E Jr, Kandaswami C, Theoharides TC. The effects of plant flavonoids on mammalian cells: implications for inflammation, heart disease, and cancer. Pharmacol Rev, 2000; 52(4): 673-751.

Moon K, Katolkar P, Khadabadi SS. In vitro antioxidant activity of methanolic extract of Erythrinia indica. Der Pharmacia Lettre, 2010; 2:16-21.

Muthukrishnan S, Manogaran P. Phytochemical analysis and free radical scavenging potential activity of Vetiveria zizanioides Linn. J Pharmacogn Phytochem, 2018; 7(2):1955-60.

Poullain C, Girard-Valenciennes J, Smadja J. Plants from reunion island: evaluation of their free radical scavenging and antioxidant activities. J Ethnopharmocol, 2004; 95(1):19-26.

Rajinder K, Thukral AK, Saroj A. Attenuation of free radicals by an aqueous extract of peels of Safed musli tubers (Chlorophytumborivilianum Sant et. Fernand). J Chin Clin Med, 2010; 5:7-11.

Robak J, Gryglewski RJ. Flavonoids are scavengers of superoxide anions. Biochem Pharmacol, 1988; 37(5):837-41.

Rosangkima G, Jagetia GC. In vitro anticancer screening of medicinal plants of Mizoram state, India, against Dalton's lymphoma, MCF-7 and Hela cells. Int J Recent Sci Res, 2015; 6(8):5648-53.

Seifried HE, Anderson DE, Fisher EI. A review of the interaction among dietary antioxidants and reactive oxygen species. J NutrBiochem, 2007; 18:567-79.

Shantabi L, Jagetia GC, Ali MA, Singh TT, Devi SV. Antioxidant potential of Croton caudatus leaf extract in vitro. Trans Med Biotech, 2014; 2(6):1-15.

Sharma HK, Chhangte L, Dolui AK. Traditional medicinal plants of Mizoram, India. Fitoterapia, 2001; (72):146-161.

Siama Z, Lalmuansangi C, Zosangzuali M, Tochhawng L, Jagetia GC. Assessment of free radical scavenging activity and antioxidant mediated hepatoprotective effects of Mallotus roxburghianus Muell. in doxorubicin induced oxidative stress in Swiss albino mice. IJPSR, 2018; 9(10):4138-4150.

Siju EN, Rajalakshmi GR, Kavitha VP, Joseph A. In vitro antioxidant activity of Mussaenda frondosa. Int J Pharm Tech Res, 2010; 2(2): $1236-40$

Singh N, Rajini PS. Antioxidant-mediated protective effects of potato peel extract in erythrocytes against oxidative damage. Chem Biol Interact, 2008; 173(2): 97-104.

Statdtman ER. Protein oxidation and aging. Science, 1992; 257(5074):1220-4

Tiwari AK. Imbalance in antioxidant defence and human diseases. Multiple approach of natural antioxidants therapy. Curr Sci, 2001 81(9):1179-87.

Tochhawng L, Deng S, Pervaiz S, Yap CT. Redox regulation of cancer cell migration and invasion. Mitochondrion, 2013; 13(3):246-53.

Valko M, Leibfritz D, Moncol J, Cronon MT, Mazur M, Telser J. Free radicals and antioxidants in normal physiological functions and human disease.Int J Biochem Cell Biol, 2006; 39(1):44-84.

Wang J, Yao H. Antioxidant activity of feruloylated oligosaccharides from wheat bran. Food Chem, 2005; 90(4):759-64. 
Wink M, Schmeller T, Latz-Briining B. Modes of action of allele chemical alkaloids: Interaction with neuro receptors, DNA and other molecular targets. J Chem Ecol, 1998; 24:1888-937.

Zhou H, Zhang H, Yang S. Phenolic compounds and its antioxidant activities in ethanolic extracts from seven cultivars of Chinese jujube. Food Science and Human Wellness, 2014, 3:183-90.

\section{How to cite this article:}

Lalremruati M, Lalmuansangi C, Siama Z. Free radical scavenging activity and antioxidative potential of various solvent extracts of Mussaenda macrophylla Wall: An in vitro and ex vivo study. J Appl Pharm Sci, 2019;9(12): 094-102. 